\title{
The context of leprosy in Brazil-Paraguay border
}

\section{O contexto da hanseníase na fronteira Brasil/Paraguai}

\author{
Maria Elizabeth Araujo Ajalla ${ }^{1}$ \\ Sonia Maria Oliveira de Andrade ${ }^{1}$ \\ Edson Mamoru Tamaki ${ }^{1}$ \\ William Waissmann ${ }^{2}$ \\ Sandra Helena Correia Diettrich ${ }^{1}$ \\ Baldomero Antônio Kato da Silva ${ }^{3}$
}

${ }^{1}$ Departamento de Saúde Pública, Universidade Federal de Mato Grosso do Sul. Cidade Universitária, Universitário. 79070-900

Campo Grande MS Brasil. mabeajalla@gmail.com

${ }^{2}$ Escola Nacional de Saúde

Pública, Fiocruz.

${ }^{3}$ Universidade Federal do

Piauí.

\begin{abstract}
In Brazil, leprosy is endemic in three regions: the North, Northeast, and Mid-West. Counties with contiguous binational urban areas are characterized by a constant flow of people, goods, and services, which facilitates the transmission of diseases and influences the epidemiological profile of leprosy. The purpose of this study was to examine territorial differences in relation to the incidence of leprosy, focusing on border counties with contiguous binational urban areas or otherwise. Each county was taken as an information unit for leprosy cases reported during 2001-2011, based on data from original notification records of the state's Department of Health. In counties with contiguous binational urban areas detection rates showed tendency to increase, Virchowian (lepromatous) disease and disability grade II predominated when compared with Groups II and III: 0.64 and 0.54/100,000 inhabitants for Virchowian desease and 0.14 and 0.27/100,000 inhabitants for disability grade II respectively, and were associated with higher transmission rates. The findings demonstrate the role of border areas in maintaining the endemicity of leprosy.
\end{abstract}

Key words Leprosy, Border area disease, Epidemiology
Resumo A hanseníase no Brasil é endêmica em três regiões: norte, nordeste e centro-oeste. As cidades com áreas urbanas contíguas entre o Brasil e Paraguai têm como característica intenso fluxo de pessoas, bens e serviços, cuja mobilidade favorece a transmissão de doenças e influencia no perfil epidemiológico da hanseníase. O objetivo do estudo é analisar as diferenças territoriais relacionadas aos casos de hanseníase, considerando os municípios da linha de fronteira com e sem áreas urbanas contiguas e demais municipios de Mato Grosso do Sul. Cada município foi tratado como unidade de informação para os casos de hanseníase notificados no período de 2001 a 2011, sendo os dados obtidos a partir da base de dados composta pelas fichas de notificação originais da Secretaria de Estado de Saúde. Em municípios com áreas urbanas contiguas, a detecção de casos mostra tendência de aumento, maior coeficientes da forma clínica virchowiana e grau de incapacidade II, em relação aos grupos II e III, que apresentaram 0,64 e 0,54/100.000 da forma clínica virchowiana, respectivamente, e 0,14 e 0,27/100.000, respectivamente, para o grau II de incapacidade. Situação que implica no aumento da transmissão da doença e configura o território de fronteira como cidade urbana contigua importante na manutenção da hanseníase como endêmica.

Palavras-chave Hanseníase, Doença de área de fronteira, Epidemiologia 


\section{Introduction}

In Brazil, the burden of both infectious and parasitic diseases concomitant with non-communicable illnesses complicates the Brazilian health scenario. Nonetheless, the reduction and even eradication of some infectious and parasitic diseases, achieved through immunization programs, vector-control initiatives, and environmental sanitation, have proven insufficient to ensure the expected epidemiological transition ${ }^{1}$.

This situation, which stems from factors such as the occupation of urban areas and production processes aimed at the accumulation of capital at the expense of environmental preservation, is marked by the emergence of new illnesses and changes in the epidemiological behavior of longknown ailments ${ }^{1,2}$.

As a result of the prevailing social inequality and paucity of welfare measures, the disease burden has grown in the country, calling for increasingly more accurate and well-delimited epidemiological analyses to describe the living conditions of a given population in a given territory ${ }^{2}$.

Brazil's huge territorial diversity and its 15 $000 \mathrm{~km}$-long border with ten countries translate into a wide range of local features, often unique, that directly shape disease transmission ${ }^{3-5}$.

In Mato Grosso do Sul state, in the Mid-West region, 11 counties border Paraguay and one shares a border with Bolivia. With a total population of 308909 in 2011, most of these counties have small areas and low demographic density, the exception being Corumbá, with 100000 residents. Binational urban areas are contiguous in six counties (dry borders in four; fluvial borders in two) and near-contiguous in three counties. The remaining three counties do not adjoin foreign urban areas ${ }^{6}$.

In Coronel Sapucaia, Paranhos, Ponta Porã, and Sete Quedas, urban contiguity and porous dry borders encourage intense cross-national flows of people, goods, and services. This fact impacts local healthcare services, both in managerial terms and by providing an environment that facilitates the dissemination of infectious and parasitic diseases, including leprosy.

According to the Ministry of Social Integration, the economic basis of border counties in Mato Grosso do Sul is livestock production and the extraction of natural resources, while productive diversity and agricultural value remain low. Lack of livestock-related production chains constitutes a major hindrance to the region's development. Tourism in the border region is pro- posed by the Ministry of Social Integration as an alternative for boosting development ${ }^{7}$.

The Mid-West Development Superintendency (Sudeco) $)^{8}$, a former governmental agency reinstituted to promote development while reducing inequalities, now places border counties among its priorities, since their agricultural production, including cattle-raising, are important contributors to gross domestic product (GDP). In border counties located in Mato Grosso do Sul and Mato Grosso states, commerce was the productive sector that most contributed (59\%) to GDP in 2009. In Group I, commerce represented over $64 \%$ of GDP in 2009 (range: $64.23 \%$ for Ponta Porã; $68.63 \%$ for Coronel Sapucaia).

In Group I counties, the human development index (HDI) ranges from a low of 0.588 in Paranhos and Coronel Sapucaia to a high of 0.701 in Ponta Porã (Sete Quedas, with 0.614 , is close to the average index value). Despite increases in the last three annual censuses, the education index (one of the components of the HDI) remained the greatest contributor to the low or medium HDI values assigned to Group I counties. Ponta Porã, for instance, had an education index of only 0.444 in 2010, despite its high HDI. In all counties in Group I, HDI is lower than that calculated for the state as a whole?

In the World Health Organization (WHO) report of August 2012 on the global situation of leprosy, Brazil accounted for $16 \%$ of new cases worldwide. In conjunction with India (58\%) and Indonesia (9\%), the three countries represent $83 \%$ of new cases detected in 2011. These numbers indicate the current level of activity of the disease in Brazil ${ }^{10}$.

However, the overall number of new cases has fallen by $41.5 \%$ across all Brazilian regions from 2003 to 2012, yet detection rates remains high in the North and Mid-West regions, maintaining the chain of transmission ${ }^{11}$. In Mato Grosso do Sul, the detection rate was 29.5 per 100000 in 2011, ranking as very high (20- to 39-per-100 000 range $)^{12}$.

Healthcare services of border counties assist their entire populations by means of the Family Health Strategy (ESF) and the Community Health Agents Program (PACS). Irrespective of nationality and legal resident status, the whole resident population is included in the statistics produced by the Brazilian Institute of Geography and Statistics (IBGE), figuring in the calculation for federal funding from the Brazilian Unified Healthcare System (SUS) to be earmarked for local use. Of all healthcare services available, immu- 
nization is the most used by foreign residents, given the permanent risk of cross-border infection ${ }^{13}$.

Epidemiological surveillance services encounter difficulties following up patients with leprosy who live across the border, as well as their close contacts, undermining the monitoring efforts aimed at ensuring cure and interrupting the chain of transmission ${ }^{13,14}$.

The purpose of this study was to understand the epidemiological profile of leprosy cases, focusing on counties with contiguous binational urban areas delimited by dry borders between Brazil and Paraguay and comparing these with other border and non-border counties in Mato Grosso do Sul.

\section{Method}

In this descriptive study conducted in Mato Grosso do Sul state, counties with contiguous binational urban areas were defined as the information units for new leprosy cases reported from 2001 to 2011. The data were collected from the original notification reports retrieved from the Mato Grosso do Sul State Department of Health and entered into spreadsheets. Inconsistent records (duplicate cases or unidentified county of residence) were excluded.

To analyze the effect of territory on detection rates, the 79 counties in the state were categorized into three groups: I: border counties with contiguous binational urban areas; II: border counties without contiguous binational urban areas; III: other counties in the state (Figure 1$)^{15}$.

The variables considered were sex, age range, educational level, clinical presentation of the disease, operational classification, number of lesions, and degree of disability. Calculation of detection coefficients was based on demographic data from the IBGE. The $z$-test for proportions was applied to analyze the following variables: clinical presentation, WHO operational classification, and degree of disability. A significance level of 5\% ( $p \leq 0.05)$ was adopted. Statistical analyses were made with the 12.5 version of SigmaPlot program.

The research was approved by the Universidade Federal de Mato Grosso do Sul research ethics committee.

\section{Results}

From 2001 to 2011, 7299 new cases of leprosy were reported in Mato Grosso do Sul. Of these,

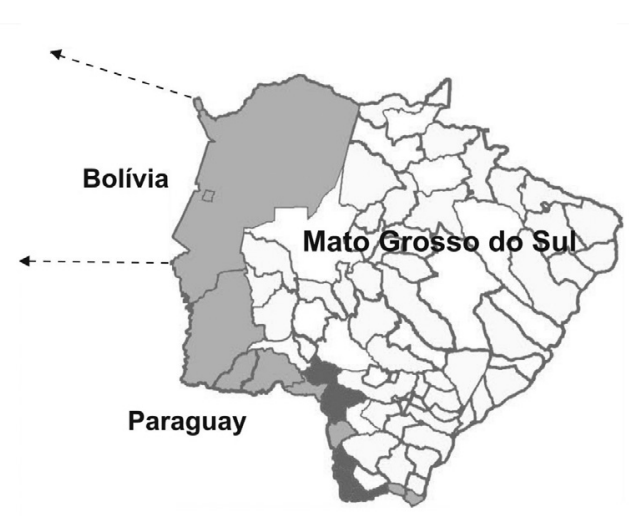

Group I Group II $\quad \square$ Group III

Figure 1. Map of Mato Grosso do Sul state-Paraguay border and non-border.

Group I: border counties with contiguous binational urban areas. Group II: border counties without contiguous binational urban areas. Group III: other counties in Mato Grosso do Sul state.

$849(11.6 \%)$ occurred in border counties (approximately 77 cases per year on average). Of the 7299 records, 25 lacked information on the county of residence and in 10 of these the place of residence was Paraguayan or Bolivian, demonstrating that patients living across the border seek healthcare services in Brazil.

Males predominated in all three groups, particularly in Group I (68.2\%) (Table 1). Adults aged 40 years and older (38.9\% in the 40 - to 59 year range) predominated in Group I. Similar results were found by Scheelbeek et al. ${ }^{16}$ for endemic areas in Cebu, Philippines, with 3288 cases in the $2000-2010$ period, $69.4 \%$ involving males. Males also predominated $(63.7 \%)$ in a study conducted by Guerrero in Colombia during the same period $^{12,17}$.

In the present investigation, patients with low educational level predominated in Group I, with $37.3 \%$ either illiterate or having less than four years of formal education (Table 1), while in Group II this rate was $17.9 \%$.

Annual detection range of new cases of leprosy per 100000 inhabitants shows tendency to increase in Group I (24- to 36-per-100000 range), while in Group II shows tendency to decrease (32- to 23-per-100000 range). In Group III there was no difference in the range (Graphic 1). 
Table 1. Leprosy cases detected in Groups I, II and III of counties, distributed by sex, age range, and number of skin lesions. Mato Grosso do Sul state, Brazil, 2001-2011.

\begin{tabular}{|c|c|c|c|c|c|c|}
\hline & \multicolumn{2}{|c|}{ Group I $(N=239)$} & \multicolumn{2}{|c|}{ Group II $(\mathrm{N}=610)$} & \multicolumn{2}{|c|}{ Group III $(\mathrm{N}=6425)$} \\
\hline & $\mathbf{n}$ & $\%$ & $\mathbf{n}$ & $\%$ & $\mathrm{n}$ & $\%$ \\
\hline \multicolumn{7}{|l|}{ Sex } \\
\hline Males & 163 & 68.2 & 331 & 54.3 & 3638 & 56.6 \\
\hline Females & 76 & 31.8 & 279 & 45.7 & 2787 & 43.4 \\
\hline \multicolumn{7}{|l|}{ Age range } \\
\hline 9 years or younger & 3 & 1.3 & 13 & 2.1 & 66 & 1.0 \\
\hline $10-19$ & 15 & 6.3 & 61 & 10.0 & 382 & 6.0 \\
\hline $20-39$ & 72 & 30.1 & 232 & 38.0 & 1935 & 30.1 \\
\hline $40-59$ & 93 & 38.9 & 201 & 33.0 & 2607 & 40.6 \\
\hline $60-69$ & 34 & 14.2 & 57 & 9.4 & 843 & 13.1 \\
\hline 70 or older & 22 & 9.2 & 46 & 7.5 & 592 & 9.2 \\
\hline \multicolumn{7}{|l|}{ Educational level } \\
\hline Illiterate & 25 & 10.5 & 29 & 4.8 & 513 & 8.0 \\
\hline Less than 4 years & 64 & 26.8 & 80 & 13.1 & 1326 & 20.6 \\
\hline 4 years (elementary school diploma) & 24 & 10.0 & 55 & 9.0 & 813 & 12.7 \\
\hline $5-7$ years & 58 & 24.3 & 131 & 21.5 & 1372 & 21.4 \\
\hline 8 years (middle school diploma) & 7 & 2.9 & 81 & 13.3 & 479 & 7.5 \\
\hline $9-10$ years & 9 & 3.8 & 79 & 13.0 & 435 & 6.8 \\
\hline 11 years (high school diploma) & 3 & 1.3 & 20 & 3.3 & 187 & 2.9 \\
\hline Higher education, incomplete & 3 & 1.3 & 4 & 0.7 & 27 & 0.4 \\
\hline Higher education diploma & 3 & 1.3 & 39 & 5.6 & 110 & 1.7 \\
\hline Not applicable & 0 & 0 & 5 & 0.8 & 52 & 0.8 \\
\hline Unknown & 43 & 18.0 & 87 & 14.3 & 1111 & 17.3 \\
\hline
\end{tabular}

Source: Original records from the Mato Grosso do Sul State Department of Health. Group I: border counties with contiguous binational urban areas. Group II: border counties without contiguous binational urban areas. Group III: other counties in Mato Grosso do Sul state.

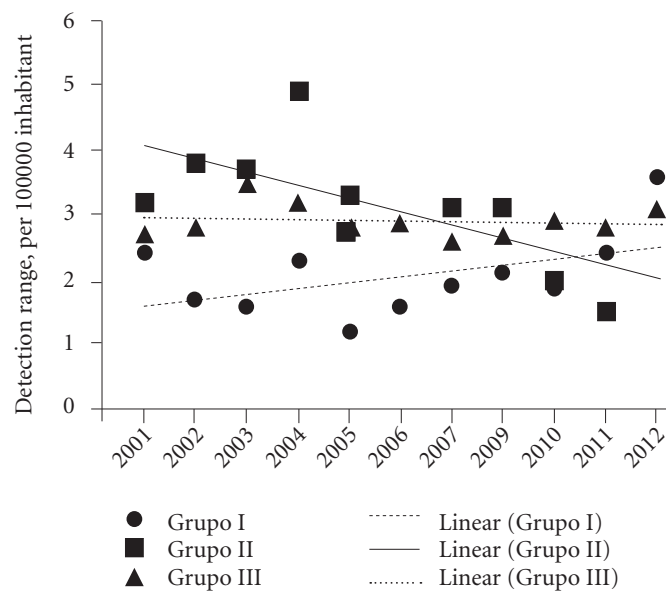

Graphic 1. Leprosy detection range, per 100000 inhabitants, distributed in border and non-border counties, Mato Grosso do Sul state, Brazil, 2001-2011.

Group I: border counties with contiguous binational urban areas. Group II: border counties without contiguous binational urban areas. Group III: other counties in Mato Grosso do Sul state.
Statistical analysis of average detection ranges during the period, showed significant differences between Group I and Groups II and III, Group I presents a lower average when compared with Groups II and III. Significant differences $(p<$ 0.05 ) were found between Group I and the other groups for tuberculoid clinical presentation of leprosy. No significant differences $(p>0.05)$ were found for dimorphous disease (Table 2).

As presented in Table 2, significant differences were not found between the Groups for Grade 0 and $1(p>0.05)$. For Grade 2 there was significant differences between all the groups.

\section{Discussion}

In Brazil, border counties tend to be viewed as territories of degradation, as they are often marked by organized crime, human trafficking, and smuggling, which ultimately hamper economic development and the improvement of the social structure, exacerbating inequalities. This 
Tabela 2. Leprosy average detection range per 100000 inhabitants in Groups I, II and III of counties, distributed by disability grade, detection mode, clinical presentation, WHO operational classification and number of skin lesions. Mato Grosso do Sul state, Brazil, 2001-2011.

\begin{tabular}{|c|c|c|c|c|}
\hline Variable & $\begin{array}{c}\text { Group I } \\
(n=239)\end{array}$ & $\begin{array}{l}\text { Group II } \\
(n=610)\end{array}$ & $\begin{array}{l}\text { Group III } \\
(\mathrm{n}=6425)\end{array}$ & $\begin{array}{c}\text { p- } \\
\text { value }^{*}\end{array}$ \\
\hline Average detection range & $2.02 \pm 0.52$ & $3.06 \pm 0.93$ & $2.91 \pm 0.26$ & 0.002 \\
\hline \multicolumn{5}{|l|}{ Clinical presentation } \\
\hline Virchowian & $0.80 \pm 0.12^{\mathrm{a}}$ & $0.64 \pm 0.10^{\mathrm{a}}$ & $0.54 \pm 0.02^{\mathrm{a}}$ & 0.129 \\
\hline Dimorphous & $0.51 \pm 0.10^{\mathrm{a}}$ & $0.77 \pm 0.09^{\mathrm{a}}$ & $0.70 \pm 0.03^{\mathrm{a}}$ & 0.069 \\
\hline Indeterminate & $0.34 \pm 0.08^{\mathrm{b}}$ & $1.07 \pm 0.22^{\mathrm{a}}$ & $0.64 \pm 0.05^{\mathrm{ab}}$ & 0.004 \\
\hline Tuberculoid & $0.20 \pm 0.05^{\mathrm{c}}$ & $0.51 \pm 0.05^{\mathrm{b}}$ & $0.70 \pm 0.04^{\mathrm{a}}$ & $<0.001$ \\
\hline Unknown & $0.21 \pm 0.06^{\mathrm{ab}}$ & $0.10 \pm 0.02^{\mathrm{b}}$ & $0.34 \pm 0.06^{\mathrm{a}}$ & 0.010 \\
\hline \multicolumn{5}{|l|}{ Operational classification } \\
\hline Multibacillary & $0.44 \pm 0.08^{\mathrm{b}}$ & $1.58 \pm 0.13^{\mathrm{a}}$ & $1.36 \pm 0.09^{\mathrm{a}}$ & $<0.001$ \\
\hline Paucibacillary & $1.59 \pm 0.14^{\mathrm{a}}$ & $1.50 \pm 0.27^{\mathrm{a}}$ & $1.56 \pm 0.08^{\mathrm{a}}$ & 0.926 \\
\hline Unknown & $0.03 \pm 0.02^{\mathrm{a}}$ & - & $0.01 \pm 0.00^{\mathrm{a}}$ & $0.343^{* *}$ \\
\hline \multicolumn{5}{|l|}{ Number of skin lesions } \\
\hline None & $0.53 \pm 0.21^{\mathrm{a}}$ & $0.86 \pm 0.28^{\mathrm{a}}$ & $0.62 \pm 0.16^{\mathrm{a}}$ & 0.554 \\
\hline Unique & $0.23 \pm 0.06^{\mathrm{b}}$ & $0.61 \pm 0.14^{\mathrm{a}}$ & $0.76 \pm 0.06^{\mathrm{a}}$ & 0.001 \\
\hline 2-5 lesions & $0.39 \pm 0.08^{\mathrm{b}}$ & $1.06 \pm 0.15^{\mathrm{a}}$ & $0.78 \pm 0.06^{\mathrm{a}}$ & $<0.001$ \\
\hline 6-10 lesions & $0.54 \pm 0.10^{\mathrm{a}}$ & $0.37 \pm 0.06^{\mathrm{a}}$ & $0.47 \pm 0.05^{\mathrm{a}}$ & 0.283 \\
\hline 11-20 lesions & $0.18 \pm 0.05^{\mathrm{a}}$ & $0.10 \pm 0.04^{\mathrm{a}}$ & $0.19 \pm 0.03^{\mathrm{a}}$ & 0.225 \\
\hline Over 21 lesions & $0.02 \pm 0.01^{\mathrm{a}}$ & $0.06 \pm 0.02^{\mathrm{a}}$ & $0.06 \pm 0.01^{\mathrm{a}}$ & 0.233 \\
\hline Unknown & $0.18 \pm 0.08^{\mathrm{a}}$ & - & $0.05 \pm 0.02^{\mathrm{a}}$ & $0.181^{* *}$ \\
\hline \multicolumn{5}{|l|}{ Degree of disability } \\
\hline Grade 0 & $0.58 \pm 0.15^{\mathrm{a}}$ & $1.07 \pm 0.22^{\mathrm{a}}$ & $0.13 \pm 0.17^{\mathrm{a}}$ & 0.086 \\
\hline Grade 1 & $0.64 \pm 0.09^{a}$ & $0.89 \pm 0.22^{\mathrm{a}}$ & $1.06 \pm 0.11^{\mathrm{a}}$ & 0.150 \\
\hline Grade 2 & $0.38 \pm 0.07^{\mathrm{a}}$ & $0.14 \pm 0.03^{\mathrm{b}}$ & $0.27 \pm 0.03^{\mathrm{ab}}$ & 0.002 \\
\hline Not evaluated & $0.20 \pm 0.07^{\mathrm{b}}$ & $0.65 \pm 0.14^{\mathrm{a}}$ & $0.29 \pm 0.02^{\mathrm{b}}$ & 0.003 \\
\hline Unknown & $0.26 \pm 0.06^{\mathrm{a}}$ & $0.33 \pm 0.13^{\mathrm{a}}$ & $0.18 \pm 0.04^{\mathrm{a}}$ & 0.461 \\
\hline \multicolumn{5}{|l|}{ Detection mode } \\
\hline Referral & $0.69 \pm 0.09^{b}$ & $1.44 \pm 0.20^{\mathrm{a}}$ & $1.11 \pm 0.05^{\mathrm{ab}}$ & 0.001 \\
\hline Spontaneous demand & $1.02 \pm 0.10$ & $1.44 \pm 0.20$ & $1.20 \pm 0.04$ & 0.093 \\
\hline Collectivity exam & $0.03 \pm 0.02^{\mathrm{b}}$ & $0.02 \pm 0.01^{\mathrm{b}}$ & $0.18 \pm 0.02^{\mathrm{a}}$ & $<0.001$ \\
\hline Contact exam & $0.20 \pm 0.08^{\mathrm{a}}$ & $0.14 \pm 0.05^{\mathrm{a}}$ & $0.31 \pm 0.04^{\mathrm{a}}$ & 0.121 \\
\hline Other modes & $0.06 \pm 0.03^{\mathrm{a}}$ & $0.02 \pm 0.01^{\mathrm{a}}$ & $0.07 \pm 0.01^{\mathrm{a}}$ & 0.154 \\
\hline Ignored & $0.05 \pm 0.03^{\mathrm{a}}$ & $0.01 \pm 0.01^{\mathrm{a}}$ & $0.05 \pm 0.01^{\mathrm{a}}$ & 0.170 \\
\hline
\end{tabular}

The results are presented in average \pm standard average error. ${ }^{*} \mathrm{P}$-value in one-way ANOVA. " ${ }^{\text {* }}$-value in student's $\mathrm{t}$-test. Different letters indicate significant difference between the groups (Tukey post test, $\mathrm{p}<0.05$ ). Group I: border counties with contiguous binational urban areas. Group II: border counties without contiguous binational urban areas. Group III: other counties in Mato Grosso do Sul state.

view, however, is being re-evaluated, and political and administrative efforts are being made against this situation, with a focus on economic development. Nonetheless, economic development may not in itself prove sufficient to reduce inequalities, improve the provision of essential services, including healthcare, and promote empowerment towards full citizenship ${ }^{18-20}$.

All counties in Group I are small and have healthcare structures of low to mid-level com- plexity, which assist not only Brazilian citizens living in Brazil and Paraguay, but also foreigners. The highest demand is for primary care services. Difficulties arise, however, when the assistance provided to foreign patients requires referral to higher-complexity services ${ }^{13}$.

The growth trend in new case detection in Group I is probably related more to the endemic expansion than to diagnostic and treatment quality. One example is the higher number of 
new cases in grade 2 of disability in Group I than Group II and III, showing late diagnosis.

The study results show that detection average coefficients indicate similarity between Groups II and III. Group II counties have commercial, cultural and healthcare relationships with other counties in Mato Grosso do Sul state.

Educational level also translates into inferior working conditions and lower income. In Group I counties, $37.5 \%$ of patients were illiterate or had not completed elementary school. This rate was $17.9 \%$ for Group II and $28.6 \%$ for Group III. In Group I, the severity of clinical presentation (mostly Virchowian) adds to the already high social vulnerability stemming from the low educational level.

The economy, HDI, and healthcare structure of Group I counties were similar to those of Group II, yet insufficient to explain the differences found among the three groups. One reason for the higher flow of people, goods, and services in Group I counties is the fact that many Brazilian citizens choose to live in Paraguay because of the lower cost of housing. Conversely, many Paraguayan citizens seek jobs, often menial, in Brazil ${ }^{21}$.

The presence of a political-administrative border that officially delimits, but is ignored in everyday life, has been a historical trait of these counties, ensuring a continuous cultural exchange that makes these territories unique urban centers, blending characteristics from both coun$\operatorname{tries}^{22-24}$.

In these counties, leprosy has a profile shaped not only by the etiological agent, but also by features pertaining to patient and territory. Of the ten patients who resided in Paraguay but were reported and treated in Brazil, six had the Virchowian presentation. Although this number is too low for conclusive analysis, it draws attention to the preoccupation about the proximity of the two countries. The fact that Paraguayan patients were diagnosed in Brazil can be explained by their easier access to diagnosis and treatment in Brazilian territory.

According to the Paraguayan Ministry of Public Health and Social Welfare ${ }^{25}$, the rates of leprosy prevalence in the departments of Amambay and Canindeyú were 0.7 and 0.8 per 10000 in 2009 , respectively, while the national rate was 0.6. These are the departments that share a border with Brazil. Rates calculated at departmental level, however, may mask extreme values, although Paraguay has attained the WHO goal of less than one case per 10000 population, making leprosy a less relevant public health problem than in counties within Mato Grosso do Sul.

\section{Conclusion}

Males with low educational level and aged 40 years or older predominated in new cases of leprosy occurring in Mato Grosso do Sul state counties with contiguous binational urban areas delimited by a dry border (Group I).

Leprosy case detection in Group I showed tendency to increase, implying greater transmission of the disease and characterizing it as endemic, posing difficulties for compliance with WHO's resolution on the eradication of leprosy by 2015 (prevalence of less than 1 case per 10 000 population). The WHO advocates action to improve the access of vulnerable populations to healthcare services where coverage is low, as is the case with the counties investigated in the present study ${ }^{26,27}$.

The detection of grade II disability at the time of diagnosis indicates that the disease is often diagnosed late, revealing a pressing need to improve the quality of healthcare services in Brazilian counties along the Paraguayan border, particularly those with contiguous binational urban areas, as well as the need to improve the socioeconomic status of this territory.

Leprosy surveillance hinges on two key actions: timely detection of new cases and treatment until a cure is attained. Improving the quality of healthcare services is also crucial for effective monitoring of new cases in the counties investigated. This qualitative improvement requires greater knowledge of the population dynamics in this territory, including flows motivated by demands for goods and services, healthcare services included.

\section{Limitations of this study}

One limitation of the present study is that the data for the four counties with contiguous binational urban areas delimited by a dry border (Group I) were pooled into a single group. Although this was done in order to better compare them with border counties without contiguous binational urban areas (Group II) and other counties in Mato Grosso do Sul state (Group III), the procedure may have obscured specific features of each county pertaining to Group I. 


\section{Collaborations}

MEA Ajalla worked in the research conception, data gathering, database organization and analysis. SMO Andrade worked in the research conception and methodology. SHC Diettrich worked in the research methodology and discussion. W Waissmann worked in the research conception, data analysis and conclusions. BAK Silva worked in the database organization and statistical analysis. EM Tamaki worked in the database organization and discussion.

\section{References}

1. Barata RdCB. O desafio das doenças emergentes e a revalorização da epidemiologia descritiva. Rev Saude Publica 1997; 31(5):531-537.

2. Cesse EAP. Epidemiologia e determinantes sociais das doenças crônicas não transmissíveis no Brasil [tese]. Recife: Fundação Oswaldo Cruz; 2007.

3. Peiter P, Machado LO, Rojas LI. Saúde e vulnerabilidade na faixa de fronteira In: Barcellos C, editor. A geografia e o contexto dos problemas de saúde. Rio de Janeiro: Abrasco; 2008. p. 263-278.

4. Brasil. Ministério da Integração Nacional (MI). Secretaria de Programas Regionais. Faixa de fronteira: programa de promoção do desenvolvimento da faixa de fronteira-PDFF. Brasília: MI; 2009.

5. Castro JMd, Rodrigues-Júnior AL. A influência da mortalidade por causas externas no desenvolvimento humano na faixa de fronteira brasileira. Cad Saude Publica 2012; 28(1):195-200.

6. Tamaki EM, Ferraz AF, Pontes ERJC, Cazola LHdO, Ajalla ME, Picoli RP. O Projeto SIS-fronteira no estado de Mato Grosso do Sul. In: Souza MdLd, Ferreira LAP, Rezende VM, Branco ML, editores. A Saúde e a inclusão social nas fronteiras. Florianópolis: Fundação Boiteux; 2008. p. 177-208.

7. Imbiriba EB, Basta PC, Pereira EdS, Levino A, Garnelo L. Hanseníase em populações indígenas do Amazonas, Brasil: um estudo epidemiológico nos municípios de Autazes, Eirunepé e São Gabriel da Cachoeira (2000 a 2005). Cad Saude Publica 2009; 25(5):972-984.

8. Brasil. Superintendência de Desenvolvimento do Centro-Oeste (SUDECO). Municípios pertencentes a Faixa de Fronteira do Centro-Oeste [homepage na internet]. Brasília: SUDECO; [acessado 2014 feb 1]. Disponível em: http://www.sudeco.gov.br/municipios-faixa-de-fronteira

9. Organização Mundial da Saúde. Programa das nações Unidas para o desenvolvimento. Atlas Brasil 2013 [base de dados na internet ]. Brasília (DF). PNUD. [acessado 2013 out 14]. Disponível em: http://www.pnud.org.br/ idh/atlas2013.aspx?indiceaccordion $=1 \&$ li=li_atlas2013

10. World Health Organization (WHO). Leprosy: update on the 2012 situation: WHO. Weekly epidemiological record. Geneve: WHO; 2012.

11. Brasil. Ministério da Saúde (MS). Secretaria de Vigilância em Saúde. Boletim Epidemiológico: situação epidemiológica da hanseníase no Brasil - análise de indicadores selecionados na última década e desafios para eliminação. Brasília: MS; 2013.

12. Departamento de informática do Sistema Único de Saúde. Informações de Saúde: taxa de incidência da hanseníase [base de dados na internet]. Brasília: Ministério da Saúde; 2012 [acessado 2014 fev 16]. Disponível em: http://tabnet.datasus.gov.br/cgi/tabcgi.exe?idb2012/d0206.def

13. Cazola LHdO, Pícoli RP, Tamaki EM, Pontes ERJC, Ajalla MEA. Atendimento a brasileiros residentes na fronteira Brasil-Paraguai pelo Sistema Único de Saúde. Rev. Panam Salud Publica 2011; 29(3):185-190.

14. Silva-Sobrinho RA, Andrade RLP, Ponce MAZ, Wysocki AD, Brunello ME, Scatena LM, et al. Retardo no diagnóstico da tuberculose em município da tríplice fronteira Brasil, Paraguai e Argentina. Rev. Panam Salud Publica 2012; 31(6):461-468. 
15. Cidades. [homepage na internet]. Brasília (DF):Instituto Brasileiro de Geografia e Estatística; [acessado 2014 mar 29]. Disponível em: http://www.cidades.ibge.gov. $\mathrm{br} / \mathrm{xtras} / \mathrm{uf} . \mathrm{php}$ ?lang $=\& \operatorname{coduf}=50 \&$ search $=$ mato-grosso-do-sul.

16. Scheelbeek PFD, Balagon MVF, Orcullo FM, Maghanoy AA, Abellana J, Saunderson PR. A Retrospective Study of the Epidemiology of Leprosy in Cebu: An Eleven-Year Profile. Plos Negl Trop Dis 2013; 7(9):1-12.

17. Guerrero MI, Muvdi S, León CI. Retroso en el diagnóstico de lepra como factor pronóstico de discapacidad en una chorte de pacientes en Colombia, 2000-2010. Rev Panam Salud Publica 2013; 33(2):137-143.

18. Rodrigues-Júnior AL, Castilho EA. A AIDS nas regiões de fronteira no Brasil de 1990 a 2003. Rev Panam Salud Publica 2009; 25(1):31-38.

19. Rodrigues-Júnior AL, Castilho EA. AIDS e doenças oportunistas transmissíveis na faixa de fronteira brasileira. Rev Soc Bras Med Trop 2010; 43(5):542-547.

20. Castro JMd, Junior ALR-. A influência da mortalidade por causas externas no desenvolvimento humano na faixa de Fronteira brasileira. Cad Saude Publica 2012; 28(1):195-200.

21. Oliveira TCMd. Tipologia das relações fronteiriças: elementos para o debate teórico-práticos. In: Oliveira TCMd, editor. Território sem limites: estudo sobre fronteira. Campo Grande: UFMS ed; 2005. p. 377-408.

22. Levino A, Carvalho EFd. Análise comparativa dos sistemas de saúde da tríplice fronteira: Brasil/Colômbia/ Peru. Rev Panam Salud Publica 2011; 30(5):490-500.

23. Fedatto NASF. Educação em Mato Grosso do Sul: limitações da escola brasileira numa divisa sem limites na fronteira Brasil-Paraguai. In: Oliveira TCM, organizador. Território sem limites: estudos sobre fronteiras. Campo Grande: UFMS Ed; 2005. p. 491-510.
24. Dorfman A. A cultura do contrabando e a fronteira como um lugar de memória. Estud. Hist. [periódico na internet]. 2009 maio [acessado 2014 jan 11]; (1):[aproximadamente 10 p.]. Disponível em: http://www.retis. igeo.ufrj.br/index.php/producao/artigos/a-cultura-docontrabando-e-a-fronteira-como-um-lugar-de-memoria/.

25. Paraguay. Ministerio de Salud Pública y Bienestar Social. Dirección Geral de Información Estratégica em salud. Dirección de Bioestadística. Indicadores básicos de salud. Assunção: Ministerio de Salud Pública y Bienestar Social; 2010.

26. Brasil. Ministério da Saúde (MS). Secretaria de Vigilância em Saúde. Plano integrado de ações estratégicas de eliminação da hanseníase, filariose, esquistossomose e oncocercose como problema de saúde pública, tracoma como causa de cegueira e controle das geohelmintíases: plano de ação 2011-2015. Brasília: MS; 2010.

27. Lockwood DNJ. Leprosy elimination a virtual phenomenon or a reality? Br Med J 2002; 324(22):1516-1518.

Artigo apresentado em 16/04/2014

Aprovado em 18/04/2014

Versão final apresentada em 30/06/2014 